How to cite this work: Droogleever Fortuijn, J. (2019). Women geographers and the International Geographical Union. Boletín de la Asociación de Geógrafos Españoles, 81, 2819, 1-16. http://dx.doi.org/10.21138/bage.2819

\title{
Women geographers and the International Geographical Union
} Mujeres geógrafas y la Unión Geográfica Internacional

\author{
Joos Droogleever Fortuijn \\ j.c.droogleeverfortuijn@uva.nl \\ Department of Geography, Planning and International Development Studies \\ University of Amsterdam (The Netherlands)
}

\begin{abstract}
This article reports the under representation of women in the discipline of geography in the world and focuses on the position of women in the global geography community of the International Geographical Union IGU. First, it gives an overview of the underrepresentation of women in geography in different parts of the world, demonstrating that women are particularly underrepresented in positions of power and prestige. Second, it summarizes factors that explain the underrepresentation of women in geography. Finally, it analyzes the position of women in the governance of the IGU. It concludes that women geographers are still underrepresented in the IGU in the same way as in geography departments all over the world. The participation of women in the governance of the IGU reflects the gendered nature of subdisciplines in geography as an integrative natural sciences-social sciences-humanities discipline, with a higher share of female representation in human geography than in physical and technical subdisciplines. Female representation is more often from high-income countries in Europe, North-America and Oceania and from Latin-America than from Asia and Africa.
\end{abstract}

Key words: women geographers; gender representation in Geography; International Geographical Union. 


\section{Resumen}

Este artículo expone la infrarrepresentación de las mujeres en la Geografía alrededor del mundo y se centra en la posición de las mujeres en la comunidad global de Geografía de la Unión Geográfica Internacional (UGI). En primer lugar, hace un recorrido por la infrarrepresentación de las mujeres en la Geografía en diferentes partes del mundo, el que prueba que las mujeres están especialmente infrarrepresentadas en las posiciones de poder y prestigio. En segundo lugar, resume los factores que explican la infrarrepresentación de las mujeres en Geografía. Por último, analiza la posición de las mujeres en el gobierno de la UGI. El artículo concluye que las mujeres geógrafas están infrarrepresentadas en la UGI al igual que en los departamentos de Geografía alrededor del mundo. La participación de las mujeres en el gobierno de la UGI refleja el sesgo de género de las subdisciplinas en Geografía, como disciplina integradora de ciencias naturales, ciencias sociales y humanidades, en la que la representación de mujeres es más alta en la Geografía humana que en la Geografía física y otras subdisciplinas técnicas. La representación de las mujeres suele provenir de países de altos ingresos de Europa, Norteamérica y Oceanía y de Latinoamérica más que de Asia y África.

Key words: mujeres geógrafas; representación de género en Geografía; Unión Geográfica Internacional.

\section{Introducción}

I bear evil tidings. By every objective measure that can be mustered, the lot of the female geographer is, and has been, a discouraging one; and there is little assurance of substantial improvement during the foreseeable future. In purely numerical terms, ours is a lopsidedly male profession in which women are most conspicuous by their absence or rarity. Furthermore, the evidence indicates that, just as in any other scientific discipline, any young woman contemplating a professional career in geography can look forward to substantially less in both the short and long run in terms of material and non-material rewards, such as attainment of higher degrees, rank, appointment to prestigious institutions, salary, power, honors, office in national organizations, or the opportunity for creative scholarship, than is the case for a young man of the same age and native ability. (...) only the female geographer endowed with exceptional intellect, and character (and probably luck) has been able to realize anything close to full potential". These words are written in 1973 by former president of the Association of American Geographers, Wilbur Zelinski, in his article "The strange case of the missing female geographer" (Zelinski, 1973, pp. 101-102). 
Several articles have been published in the 45 years since Zelinski's outcry, dealing with the situation in American geography as well as other parts of the world. The message is always the same: female geographers are underrepresented in geography in general and in well-paid, permanent and powerful positions in particular. Does it mean that nothing has improved since 1973?

What are the changes in the position of female geographers globally? What is the position of women geographers in the global geography community of the International Geographical Union?

\section{Women geographers}

Before focusing on the position of women geographers in the IGU, I will give an overview of the literature regarding the position of female geographers in different parts of the world. As far as I know, the American Association of Geographers is the only organization in the world that systematically reports on the position of female geographers.

\section{Table 1. Female members of the Association of American Geographers, 1904, 1972 and 2015}

\begin{tabular}{|c|c|c|c|}
\cline { 2 - 4 } \multicolumn{1}{c|}{} & All members & $\begin{array}{c}\text { Faculty } \\
\text { members }\end{array}$ & $\begin{array}{c}\text { Student } \\
\text { members }\end{array}$ \\
\hline 1904 & $4 \%$ & - & - \\
\hline 1972 & $14 \%$ & $7 \%$ & $15 \%$ \\
\hline 2015 & $38 \%$ & $28 \%$ & $44 \%$ \\
\hline
\end{tabular}

Source: AAG Geographers by gender summary report (2016)

In 1904, the founding year of the AAG, two of the 48 members were women. In 1972, the year in which Zelinski was president, 14 percent of the AAG members were female and that percentage is currently 38 percent (Table 1). There was and is a big difference between members who are faculty in a college or university on the one hand and student members. In 1972, seven percent of the AAG members employed at a college or university were women, while twice as much of the student members were women. In 201528 percent of the faculty and 44 percent of the students were women. In summary, in 1972 female geographers were an exception in the AAG membership, while currently almost half of the students and a quarter of the faculty members are female.

Table 2. USA Faculty by rank and gender, 2018

\begin{tabular}{|l|c|c|c|}
\cline { 2 - 4 } \multicolumn{1}{c|}{} & Male & Female & All \\
\hline Full professor & $280(78 \%)$ & $80(22 \%)$ & $360(100 \%)$ \\
\hline Associate professor & $176(64 \%)$ & $99(36 \%)$ & $275(100 \%)$ \\
\hline Assistant professor & $136(60 \%)$ & $92(40 \%)$ & $228(100 \%)$ \\
\hline Instructor fulltime & $78(57 \%)$ & $58(43 \%)$ & $136(100 \%)$ \\
\hline Instructor parttime & $105(56 \%)$ & $81(44 \%)$ & $186(100 \%)$ \\
\hline All & $775(65 \%)$ & $410(35 \%)$ & $1185(100 \%)$ \\
\hline
\end{tabular}

Source: AAG Department Survey Data Tables (2018) 
Data of 67 geography departments in the USA demonstrates that the higher the rank, the more women are underrepresented. While 44 percent of the instructors are female, no more than 22 percent of the full professors are women (Table 2).

Looking at power and prestige, we can see that no more than 15 of the 114 (13 percent) AAG presidents were women. The first female president was Ellen Churchill Semple in 1921 and the next one was not until Risa Palm became president in 1984. In the past 10 years, the majority (6 of the 10) of the AAG presidents were women. Several of these women are well-known feminist geographers: Risa Palm, Susan Hanson, Janice Monk, Audrey Kobayashi and Mona Domosh (AAG, 2016).

Looking at the editors of the AAG journals, we see that 43 percent of the current editorial board members are female. The Annals have a majority of male editorial board members, The Professional Geographer has a gender balance and GeoHumanities has more female than male board members (AAG, 2016). Finally, 23 percent of the AAG Honors and Awards are awarded to women, with more female awardees in the recent past (AAG, 2016).

Women are still under represented in geography in the USA, especially in positions of power and prestige, but the position of women geographers has improved in the past 50 years, in particular in the recent past.

Since 1973, several articles have been published about the marginalisation of women geographers outside the USA in male-dominated geography departments in the UK (McDowell, 1979), Canada (Mackenzie 1989), France (Creton 2007), Netherlands (Droogleever Fortuijn, 2004), Israel (Fenster, 2011), Anglophone Africa (Awumbila, 2007) and Taiwan and Hong Kong (Chiang and Liu 2011), or in conservative, positivistic dominated geography departments in former socialist countries in East-Central Europe (Timár, 2007; Timár \& Fekete, 2010; Voiculescu, 2011), the Germanspeaking countries (Buehler \& Baechli 2007) and Brazil and Argentina (Veleda da Silva \& Lan, 2007). Some studies report substantial differences between universities in one country (GarcíaRamón et al., 1988; Kaplan \& Mapes, 2016; Longhurst, 2011). The message is almost everywhere the same: women are still under represented in geography, especially in higher ranks and the situation has improved in the long run (Brinegar, 2001; Falconer Al-Hindi, 2000; Lee, 1990; Monk et al., 2004; Peake, 2017), although the situation is different in different countries, with, for example, high shares of female faculty in Spain and low in France. Diaz Cortes et al. (2007) report a decreasing share among students and staff in Spain resulting from the transformation of geography as an education for teachers into a more professional and technical discipline.

In the Department of Geography, Planning and International Development Studies at the University of Amsterdam, the position of women has improved since 2008, the year in which I became head of department (I was head of department until 2015). In 2007, 29 percent of the tenured staff was 
female: two of the ten full professors, three of the nine associate and 11 of the 21 assistant professors. The current situation (March 2019) is almost a reversed pyramid with 45 percent of the total tenured staff being female. 45 percent of the full professors, 60 percent of the associate professors and 29 percent of the assistant professors are women. One of the female full professors became full professor in a special national program to stimulate female professorships.

The Royal Geographical Society with IBG in the UK, founded in 1830, had the first female president not until 2002, the French Comité National Français de Géographie in 2005 and the Hong Kong Geographical Association in 2007, while many national geographical societies never had a female president.

\section{Understanding the position of women geographers}

Geography was and still is a male-dominated discipline. Why? The literature on the position of women geographers indicates many factors that explain the under representation of women in the discipline. Several factors are general, explaining the gendered nature of science and society in general; some factors, however, are specific for the discipline of geography.

An important general factor is the socialization of women in traditional gender roles: women grow up and are educated in a system that prepares women more for a role as housewife and mother than for the labour market (Zelinski, 1973). As a consequence, women are less active at the labour market and are more often part time employed than men. However, in many countries the gender differences in labour market participation are minimal.

More important are mechanisms in male dominated sectors that exclude women, except the extreme clever and motivated ones. Female students in male-dominated disciplines lack role models, in particular at the level of full professors, mentoring by senior female faculty, relevant networks and tacit knowledge (Caretta et al., 2018; Hanson, 2000; Lee, 1990; Solem et al., 2011). In many countries we see a gender balance among students at the undergraduate level. Although female students perform equal to or even better than male students, female students are underrepresented in master and PhD programs in many countries (Brinegar, 2001; Kaplan \& Mapes, 2016; McDowell, 1979).

Several studies refer to gendered mechanisms in the recruitment and promotion procedures for faculty. In short: male-dominated disciplines have usually male-dominated search committees with a tendency to recruit new, like-minded faculty, that is male faculty (Domosh, 2000; Peake, 2017; Winkler, 2000). Seager (2000) published an analysis of letters of application and letters of recommendation for academic functions in geography in an article titled "And a charming wife: Gender, marriage and manhood in the job search process". She demonstrates the hidden 
assumption that geography faculty are male, heterosexual married men, preferably "with a charming wife" - nobody is speaking about a "charming husband" or a charming homosexual partner.

Finally, female geographers who are employed in academia, meet several barriers to survive in an academic environment and to make progress in an academic career. Gill Valentine (1998) reports overt sexual harassment and discrimination in her article titled "Sticks and stones may break my bones: a personal geography of harassment". Lesbian women and women of colour in particular are vulnerable for discrimination (Peake, 2011; Peake, 2017). Female faculty has to play a balancing act: not to be too soft and feminine and not to be too tough and masculine in behavior and appearance.

All these factors explain why male-dominated (and white) sectors and disciplines reproduce male domination and whiteness and are not specific for geography. I think that two factors are specific for geography: first, the hierarchy in subdisciplines in a discipline that integrates natural sciences, social sciences and humanities, and, second, the role of fieldwork in geography.

Natural sciences and technology usually have a lower percentage of women than social sciences and humanities. Formally, all disciplines are equally important, but some are more equal than others and usually natural sciences are higher in the academic hierarchy in terms of power, prestige and funding than social sciences and humanities. Geography is one of the very few disciplines that integrate natural sciences, social sciences and humanities. Most geographers, however, are not generalists, but specialists in one of the subdisciplines. Female geographers are more often human than physical geographers (Kaplan \& Mapes, 2016; Luzzadder-Beach \& Macfarlane, 2000) and more often specialists in 'soft' subdisciplines such as cultural geography, gender and sexuality, urban geography, or development geography than in 'hard' specialisations such as geomorphology, climatology or GIS. This factor explains the gender differences in power, in particular in countries and universities where human and physical geography are integrated.

Internationally, fieldwork is generally seen as a key characteristic of the geography discipline (Fuller et al., 2006; Robson, 2002). The emphasis on fieldwork is closely connected with the development of geography in the 19th century and geographers' role in the exploration of unknown areas (unknown to European societies of course). Geographers were supposed to be white, able-bodied, tough, adventurous men. Nairn (2005) and Kent et al. (1997) criticized this image of heroism and the exclusionary practices and processes involved, excluding females, gays, disabled students, minority students and older students (Droogleever Fortuijn, 2009).

\section{Women geographers in the International Geographical Union}

As an introduction to the analysis of the position of women geographers in the IGU, I have to explain the membership structure of IGU. Unlike the AAG and other national geographical associations or 
societies, formal members of IGU are not people but country members, the national IGU committees, usually representatives of the geography departments in the country. The chairs of the national IGU committees form the General Assembly of the IGU that elects president, secretarygeneral and vice-presidents, and decides about the foundation and continuation of Commissions and commission chairs.

Most important are the Commissions, because they organize the majority of the activities and produce publications. Commissions have members, with a total of about 10,000 worldwide from more than 100 countries, but IGU has no list of commission members. All Commissions have a chair and a steering committee of about 11 members. Commissions report annually about their membership, but only about membership per country and not gender. So, because of the specific membership structure, I am not able to analyse the gender composition of IGU Commission members, but I can analyse the gender composition of the people who are responsible for the IGU governance: presidents, secretary-generals, vice-presidents and Commission chairs and steering committee members, and the IGU honors.

Since the foundation of IGU in 1922, IGU had 25 presidents (https://igu-online.org/), and only one of them was a woman: the Irish Anne Buttimer who was president from 2000-2004. This situation is more like the situation in the British RGS and the French CNFG than in the American AAG. Anne Buttimer was one of the most important humanistic geographers, specialized in the philosophy and history of geography. She had an exceptional career, starting as a teacher and a nun before she completed a PhD in geography. She was a cosmopolitan geographer, employed as full professor at universities in the USA, Sweden, France, Canada and Ireland.

IGU had 14 secretary-generals, one of them was a woman: Marguerite Lefèvre from Belgium, who was elected as secretary-general jointly with Paul Michotte van den Berck in 1938 (BESTOR, 2019). After Paul Michotte passed away in 1940, she continued as secretary-general until 1949. Marguerite Lefèvre, born in 1894, had a remarkable career, although Janice Monk's (2004) analysis of women geographers in the USA in the first half of the 20th century demonstrates that such a career was quite common for female geographers at that time. According to Janice Monk the Normal School was in that period a common starting point for female geographers in the USA. Marguerite Lefevre was also a teacher before she became secretary of Paul Michotte, who was a full professor and director of the Institute of Geography at the Catholic University of Louvain. After some years she started to study geography and followed geography courses in Louvain. However, she was not allowed to take physical geography courses. I presume that the ban on field work for female students at this catholic university was one of the reasons. She went to the University of Liège for the physical geography and later to the Sorbonne in Paris where she completed a PhD in geography. She returned to Louvain and became assistant of Paul Michotte and performed an important role in the Institute of Geography, in teaching, research and management. She was a generalist and 
published on human as well as physical geography, cartography and methodology. After the death of Paul Michotte, she became director of the Institute of Geography (and continued as secretarygeneral of the IGU), but it took 20 years before she became full professor, in 1960, the first female full professor at the University of Louvain, four years before her retirement and seven years before she died in 1967.

The list of female IGU awardees (https://igu-online.org/) is slightly longer than the list of female presidents and secretary-generals. Five of the 44 Lauréats d'Honneur awardees are women: Jacqueline Beaujeu-Garnier, Yola Verhasselt, Janice Monk, Maria Dolors Garcia-Ramon and Robyn Longhurst. The Planet and Humanity Medal is awarded to eight men and two women: Gro HarlemBrundtland was the first awardee in 1996, and Mary Robinson in 2000.

Table 2. USA Faculty by rank and gender, 2018

\begin{tabular}{|l|c|c|c|}
\cline { 2 - 4 } \multicolumn{1}{c|}{} & Male & Female & All \\
\hline Full professor & $280(78 \%)$ & $80(22 \%)$ & $360(100 \%)$ \\
\hline Associate professor & $176(64 \%)$ & $99(36 \%)$ & $275(100 \%)$ \\
\hline Assistant professor & $136(60 \%)$ & $92(40 \%)$ & $228(100 \%)$ \\
\hline Instructor fulltime & $78(57 \%)$ & $58(43 \%)$ & $136(100 \%)$ \\
\hline Instructor parttime & $105(56 \%)$ & $81(44 \%)$ & $186(100 \%)$ \\
\hline All & $775(65 \%)$ & $410(35 \%)$ & $1185(100 \%)$ \\
\hline
\end{tabular}

Source: AAG Department Survey Data Tables (2018)

IGU has currently 16 female Commission chairs or co-chairs and 33 male (source: annual reports IGU Commissions). Female Commission chairs are almost all from western, high-income countries (Europe plus Anglophone countries in North-America and Oceania): 14 of the 16, predominantly from Europe, while 33 percent of the male chairs are from non-western countries and only a minority of the male chairs are from Europe (Table 3).

Table 4. (Co)chairs IGU Commissions and Task Forces by gender and subdiscipline, 2018

\begin{tabular}{|l|cc|cc|cc|}
\cline { 2 - 7 } \multicolumn{1}{c|}{} & \multicolumn{2}{c|}{ Male } & \multicolumn{2}{c|}{ Female } & \multicolumn{2}{c|}{ All } \\
\hline Human geography & 11 & $(33 \%)$ & 7 & $(44 \%)$ & 18 & $(37 \%)$ \\
\hline Mixed & 10 & $(30 \%)$ & 8 & $(50 \%)$ & 18 & $(37 \%)$ \\
\hline Physical and technical geography & 12 & $(36 \%)$ & 1 & $(6 \%)$ & 13 & $(27 \%)$ \\
\hline All & $33(100 \%)$ & 16 & $(100 \%)$ & $49(100 \%)$ \\
\hline
\end{tabular}

Source: Reports IGU Commissions and Task Forces (2018)

Human geography and mixed human-physical geography Commissions have more often a female chair or co-chair than physical or technical geography Commissions, with a slight tendency for women to chair a Commission in a 'soft' specialization, such as gender, health, urban, rural, history, education and environment, while men are more often chair in a 'hard' specialization such as transport, geomorphology, hazard, climatology, GIS and modelling (Table 4). 
Table 5. Steering committee members IGU Commissions and Task Forces

by gender and country, 2018 (33\% female steering committee members)

\begin{tabular}{|l|cc|cc|cc|}
\cline { 2 - 7 } \multicolumn{1}{c|}{} & \multicolumn{2}{c|}{ Male } & \multicolumn{2}{c|}{ Female } & \multicolumn{2}{c|}{ All } \\
\hline Europe & 100 & $(34 \%)$ & 78 & $(53 \%)$ & 178 & $(40 \%)$ \\
\hline USA, Canada, Oceania & 56 & $(19 \%)$ & 21 & $(14 \%)$ & 77 & $(17 \%)$ \\
\hline Asia & 83 & $(28 \%)$ & 26 & $(18 \%)$ & 108 & $(24 \%)$ \\
\hline Africa & 31 & $(11 \%)$ & 7 & $(5 \%)$ & 38 & $(9 \%)$ \\
\hline Latin America & 25 & $(8 \%)$ & 14 & $(10 \%)$ & 39 & $(9 \%)$ \\
\hline All & $295(100 \%)$ & $146(100 \%)$ & 441 & $(100 \%)$ \\
\hline
\end{tabular}

Source: Reports IGU Commissions and Task Forces (2018)

Similar patterns can be found in the analysis of Commission steering committee members. In the total membership we can see a domination of steering committee members from western countries, Europe in particular. One third of the steering committee members is female. Among female steering committee members, Europe is more dominant than among male members (Table 5).

Table 6. Countries with $50 \%$ or more female steering committee members of IGU Commissions and Task Forces, 2018

\begin{tabular}{|l|l|}
\hline Algeria & Lebanon \\
Argentina & Lithuania \\
Bulgaria & Malaysia \\
Cape Verde & New Zealand \\
China Taipei & Nigeria \\
Czech Republic & Norway \\
Ecuador & Peru \\
Estonia & Portugal \\
France & Romania \\
Greece & Serbia \\
Hungary & Singapore \\
Ireland & Spain \\
Kenya & Ukraine \\
Latvia & \\
\hline
\end{tabular}

Source: Reports IGU Commissions and Task Forces (2018)

East-Central and South Europe and Latin-America are in particular regions with a gender balance or majority of female steering committee members (Table 6).

The top-8 countries among female steering committee members are France, Romania, UK, USA, Germany, Spain, Canada and Brazil and among male steering committee members USA, Japan, China Beijing, Germany, UK, Australia, Canada and South Africa.

Commissions with 50 or more percent female steering committee members are the Commissions on Gender and Geography, Health and Environment, Cold and High Altitude Regions, Urban Commission, Islands, History of Geography, Tourism, Leisure and Global Change, and Water Sustainability, and the Olympiad and Young and Early Career Task Forces. The Commissions on 
Applied Geography, Toponymy, Modeling Geographical Systems, Landscape Analysis and Landscape Planning, Information, Innovation and Technology, African Studies and Geographical Information Science have ten percent or less female steering committee members (Figure 1).

Figure 1. Percentage steering committee members of IGU Commissions and Task Forces, 2018

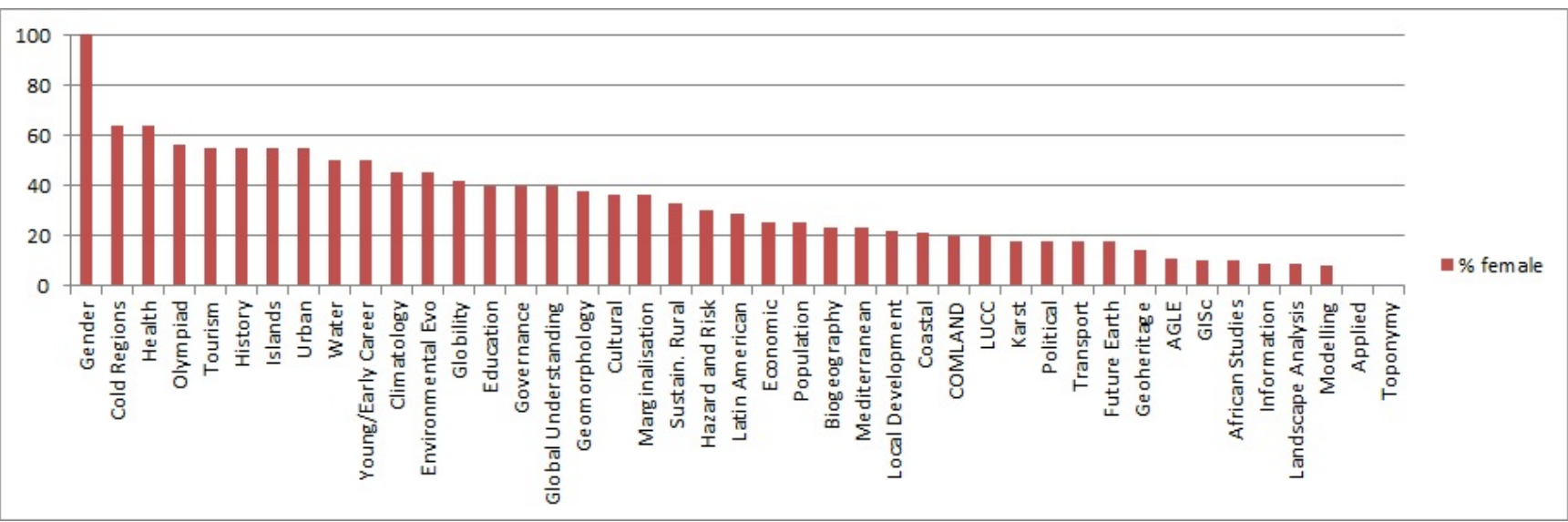

Source: Reports IGU Commissions and Task Forces (2018)

Since 1952, nine of the 78 (12 percent) IGU vice-presidents were female. The first female vicepresident was elected in 1984: Maria Gutierez de MacGregor. Three vice-presidents were from Latin-America (Maria Gutierez de MacGregor, Brazil, Bertha Becker, Brazil and Irasema Ayala, Mexico), one from Nigeria (Folasade lyun), four from Europe (Anne Buttimer, Ireland, Joos Droogleever Fortuijn, Netherlands, Elena Dell'Agnese, Italy and Nathalie Lemarchand, France) and one from Australia (Ruth Fincher). Two periods, 1996-2000 and 2016-now, the EC had three vicepresidents; in the other periods the number of female vice-presidents was one (1984-1996 and 2012-2014) or two (2008-2012 and 2014-2016) (IGU Bulletins 1952-2018).

When I became vice-president in 2012, I was the only female EC-member and had an origin in the Gender Commission. So, I was somewhat concerned about my position in a male-dominated EC. This was one of the issues that I discussed with Ruth Fincher who was vice-president in 2008-2012 and also a former chair of the Gender Commission. She told me that it was not a problem at all: she experienced the EC presided by Ron Abler as 'fair'. My own experiences are similar: I experienced respect first and friendship later.

One of my duties is a new initiative: chairing the subcommittee that nominates one of the Commissions for the IGU Commissions Excellence Award. Criteria for the award are activities, publications, funding, collaboration with other IGU Commissions and external organisations, and stimulation of young geographers, female geographers and geographers from developing countries. The price is some money and a keynote lecture at one of the IGU congresses or conferences. In the first year, after reading the Commission's annual reports, it was crystal clear for 
me that the Gender Commission was the best performing one and should be awarded. I was, however, thinking about the difficulties that the founders of the Gender Commission, Janet Momsen, Janice Monk and Maria Dolors Garcia Ramon, had to get the approval of the Executive Committee and General Assembly in 1988 and 1992 (Huang et al., 2017; Monk, 2008). As a former chair of the Commission, I realized that the other EC members might have a different opinion. So, how to convince them? I employed what Sorina Voiculescu (see Timar \& Fekete, 2010) and Mariama Awumbila (2007) call a typical male strategy of producing 'numbers, ratios and gaps". I produced an excel table with measures and numbers for each of the criteria. Although everyone in the EC appreciated the excel summary, it was not necessary to convince them: all members agreed with Ron Abler that "the Commission on Gender and Geography has been consistently more active and productive than any other commission". So, the Gender Commission was the first awardee. The awardees in the years after were the Commission on Political Geography, the Commission on Geographical Education, the Commission on the Mediterranean Basin and the Commission on Tourism, Leisure and Global Change, resulting in keynote lectures presented by women: Shirlena Huang, Virginie Mamadouh, Clare Brook and Maria Paradiso.

\section{Conclusions}

Women geographers are still under represented in IGU in the same way as in geography departments all over the world. One female president and one female secretary-general is not a very good performance from a gender perspective, but 33\% female members in IGU EC, Commission chairs and steering committee members is not bad: similar as in many North-American and European countries and much better than in other parts of the world. The participation of women in the governance of the IGU reflects the gendered nature of the subdisciplines in geography as an integrative natural sciences-social sciences-humanities discipline with a higher share of female representation in human geography and 'soft' subdisciplines than in physical and technical subdisciplines.

A complicated result from the analysis is the fact that chairs and steering committee members from western countries have a higher share of female members than chairs and steering committee members from non-western countries (except Latin-America). IGU aims to stimulate the participation of female geographers, young geographers and geographers from low-income, non-western countries. Participation of female and young geographers goes hand in hand, but stimulating the participation of geographers from Asia and Africa means less female geographers.

As long as geography is a male-dominated discipline globally, we cannot expect a full gender balance within IGU. Nevertheless, IGU policy can be helpful as some recent initiatives demonstrate: the Commission Excellence Award, the new Young and Early Career Task Force and young and early career subcommissions in several Commissions, paper awards for young geographers (who 
are more often female than senior geographers), a gender balance in the IGU travel grants and the Honors and Awards Committee, chaired by a feminist geographer, Ruth Fincher, currently member of the Governing Board of the International Scientific Council. IGU might consider to create a formal requirement for a minimum level of female steering committee members of Commissions and female keynote speakers at IGU congresses and conferences. These are small steps, but important to get a greater visibility and more power of women geographers in the world.

Authorship statement: The author declares no conflict of interest. 


\section{References}

AAG (2016). Geographers by gender summary report 2016. Washington: American Association of Geographers.

AAG (2018). AAG Department Survey Data Tables 2018. Washington: American Association of Geographers.

Awumbila, M. (2007). Challenging contexts: Gender studies and geography in Anglophone African countries. Belgeo, 2007(3), 261-274. http://dx.doi.org/10.4000/belgeo.11172

BESTOR (2019). Lefèvre, Marguerite (1894-1967). Retrieved from https://www.bestor.be/wikinnl/index.php/Lef\%C3\%A8vre,_Marguerite (1894-1967)

Brinegar, S. J. (2001). Female representation in the discipline of geography. Journal of Geography in Higher Education, 25(3), 311-320. https://doi.org/10.1080/03098260120084395

Buehler, E., \& Baechli, K. (2007). From 'Migration der Frau aus Berggebieten' to 'Gender and sustainable development': Dynamics in the field of gender and geography in Switzerland and in the German-speaking context. Belgeo, 2007(3), 275-300.

http://dx.doi.org/10.4000/belgeo.11325

Caretta, M. A., Drozdzewski, D., Jokinen, J. C., \& Falconer, E. (2018). 'Who can play this game'? The lived experiences of doctoral candidates and early career women in the neoliberal university. Journal of Geography in Higher Education, 42(2), 261275. https://doi.org/10.1080/03098265.2018.1434762

Chiang, L.-H. N., \& Liu, Y.-C. (2011). Feminist geography in Taiwan and Hong Kong. Gender, Place \& Culture, 18(4), 557-569. https://doi.org/10.1080/0966369X.2011.583341

Creton, D. (2007). Gender issues in French geography. Belgeo, 2007(3), 313322. https://doi.org/10.4000/belgeo. 11201

Diaz Cortés, F., Garcia Ramon, M. D., \& Ortiz, A. (2007). Engendering Spanish geography. Belgeo, 2007(3), 323-334. https://doi.org/10.4000/belgeo.11207

Domosh, M. (2000). Unintentional transgressions and other reflections on the job search process. Professional Geographer, 52(4), 703-708. https://doi.org/10.1111/0033-0124.00259

Droogleever Fortuijn, J. (2004). Gender representation and participation in Dutch human geography departments. Journal of Geography in Higher Education, 28(1), 133141. https://doi.org/10.1080/0309826042000198701

Droogleever Fortuijn, J. (2009). Gender-sensitive observations in public spaces as a teaching tool. Geographica Helvetica, 64(1), 37-44. http://hdl.handle.net/11245/1.311494 
Falconer Al-Hindi, K. (2000). Women in geography in the 21st century. Introductory remarks: Structure, agency, and women geographers in academia at the end of the long twentieth century. Professional Geographer, 52(4), 697-702.

https://doi.org/10.1080/00330124.2000.9628415

Fenster, T. (2011). Teaching gender in Israel: experiences at the Tel Aviv university. International Research in Geographical and Environmental Education, 20(3), 195197. https://doi.org/10.1080/10382046.2011.588499

Fuller, I., Edmonson, D., France, D., Higgitt, D., \& Ratinen, I. (2006). International Perspectives on the Effectiveness of Geography Fieldwork for Learning. Journal of Geography in Higher Education, 30, 89-102. https://doi.org/10.1080/03098260500499667

García-Ramon, M. D., Castañer, M., \& Centelles, N. (1988). Women and geography in Spanish universities. Professional Geographer, 40(3), 307-315. https://doi.org/10.1111/j.0033$\underline{0124.1988 .00307 . x}$

Hanson, S. (2000). Networking. The Professional Geographer, 52(4), 751758. https://doi.org/10.1111/0033-0124.00263

Huang, S., Monk, J., Droogleever Fortuijn, J., Garcia-Ramon, M. D., \& Momsen, J. H. (2017). A continuing agenda for gender: the role of the IGU Commission on Gender and Geography. Gender, Place \& Culture, 24(7), 919-938. https://doi.org/10.1080/0966369X.2017.1343283 Kaplan, D. H., \& Mapes, J. E. (2016). Where are the women? Accounting for discrepancies in female doctorates in U.S. geography. The Professional Geographer, 68(3), 427435. https://doi.org/10.1080/00330124.2015.1102030

Kent, M., Gilbertson, D., \& Hunt, C. (1997). Fieldwork in Geography Teaching: a Critical Review of the Literature and Approaches. Journal of Geography in Higher Education, 21, 313332. https://doi.org/10.1080/03098269708725439

Lee, D. R. (1990). The status of women in geography: things change, things remain the same. Professional Geographer, 42(2), 202-211. https://doi.org/10.1111/j.0033-0124.1990.00202.x Longhurst, R. (2011). Teaching gender geography in Aotearoa New Zealand. International Research in Geographical and Environmental Education, 20(3), 17183. https://doi.org/10.1080/10382046.2011.588494

Luzzadder-Beach, S., \& Macfarlane, A. (2000). The environment of gender and science: Status and perspectives of women and men in physical geography. Professional Geographer, 52(3), 407424. https://doi.org/10.1111/0033-0124.00235 
Mackenzie, S. (1989). The status of women in Canadian geography. Operational Geographer, $7(3), 2-8$.

McDowell, L. (1979). Women in British geography. Area, 11(2), 151-154.

Monk, J. (2004). Women, gender, and the histories of American geography. Annals of the Association of American Geographers, 94(1), 1-22. hittps://doi.org/10.1111/j.14678306.2004.09401001.x

Monk, J. (2008). Connecting people, places, and ideas: Reflections on the history of the International Geographical Union Commission on Gender and Geography. Retrieved from https://igugender.wixsite.com/igugender/publications

Monk, J., Droogleever Fortuijn, J., \& Raleigh, C. (2004). The representation of women in academic geography: Contexts. climate and curricula. Journal of Geography in Higher Education, 28(1), 8390. https://doi.org/10.1080/0309826042000198657

Nairn, K. (2005). The Problems of Utilizing 'Direct Experience' in Geography Education. Journal of Geography in Higher Education, 29, 293-310.

https://doi.org/10.1080/03098260500130635

Peake, L. (2011). In, out and unspeakably about: taking social geography beyond an AngloAmerican positionality. Social \& Cultural Geography, 12(7), 757773. https://doi.org/10.1080/14649365.2011.610245

Peake, L. (2017). Women in geography. In D. Richardson, N. Castree, M. F. Goodchild, A. Kobayashi, W. Liu \& R. A. Marston (Eds.), International Encyclopedia of Geography: People, the Earth, Environment and Technology. New York:

Wiley. https://doi.org/10.1002/9781118786352.wbieg1173

Robson, E. (2002). 'An Unbelievable Academic and Personal Experience': Issues Around Teaching Undergraduate Field Courses in Africa. Journal of Geography in Higher Education, 26, 327344. https://doi.org/10.1080/0309826022000019909

Seager, J. (2000). 'And a charming wife': Gender, marriage, and manhood in the job search process. The Professional Geographer, 52(4), 709-721. https://doi.org/10.1111/0033$\underline{0124.00260}$

Solem, M. N., Lee, J., \& Schlemper, B. (2011). Departmental climate and student experiences in geography graduate programs: research for enhancing departments and graduate education. Journal of Geography in Higher Education, 35(1), 59. https://doi.org/10.1080/03098265.2010.548463 
Timár, J. (2007). Gender studies in the gender-blind post-socialist geographies of East-Central Europe. Belgeo, 2007(3), 349-370. https://doi.org/10.4000/belgeo.11217

Timár, J., \& Fekete, É. (2010). Fighting for recognition: feminist geography in East-Central Europe. Gender, Place \& Culture, 17(6), 775-790. hitps://doi.org/10.1080/0966369X.2010.517027

Valentine, G. (1998). 'Sticks and stones may break my bones': a personal geography of harassment. Antipode, 30(4), 305-332. https://doi.org/10.1111/1467-8330.00082

Veleda da Silva, S., \& Lan, D. (2007). Geography and gender studies: the situation in Brazil and Argentina. Belgeo, 2007(3), 371-382. hitps://doi.org/10.4000/belgeo.11227

Voiculescu, S. (2011). Teaching gender and geography in Romanian universities. International Research in Geographical and Environmental Education, 20(3), 189193. https://doi.org/10.1080/10382046.2011.588497

Winkler, J. A. (2000). Faculty reappointment, tenure, and promotion: barriers for women. The Professional Geographer, 52(4), 737-750. hitps://doi.org/10.1111/0033-0124.00262

Zelinski, W. (1973). The strange case of the missing female geographer. The Professional Geographer, 25(2), 101-105. https://doi.org/10.1111/j.0033-0124.1973.00101.x 